These results obviously indicate that iron metabolism is affected by hypocupræmia. Detailed results will be published elsewhere.

Institute of Zootechnics,

Kraków, ul. Karmelicka 20,

Poland.

Feb. 18.

${ }^{1}$ Sjollema, B., Biochem. Z., 267, 151 (1933).

${ }^{2}$ Rys, R., Groblewska, S., and Styezyński, H., Roczn. Nauk. Rolm., 71, B.3, 365 (1957).

${ }^{3}$ Alleroft, E., and Parker, H., Brit. J. Nutrit., 3, 205 (1949).

+ Elvehjem, A. C., Physiol. Rev., 15, 371 (1935).

s Lahey, M. E., Gubler, C. J., Chase, M. S., Cartwright, G. E., and Wintrobe, M. M., Blood, 7,1055 (1952).

${ }^{6}$ Eden, A., and Green, H., Biochem. J., 34, 1202 (1940).

"Fister, H. J., "Manual of Standardized Procedures for Spectrophotometric Chemistry", Method 1.23.3 (New York, 1949).

\section{Effect of Protein-free Diet on the Vitamin A Storage in the Rat Liver}

SEVERAL workers ${ }^{1-4}$ have reported that diets low in protein reduced the storage of vitamin $\mathrm{A}$ in the liver and increased the rate at which stored vitamin $A$ was depleted. On the basis of such data, a conclusion was drawn by investigators that protein is a necessary dietary constituent for normal storage and utilization of vitamin A. The work described here was designed to test the validity of the former hypothesis by comparing hepatic vitamin A storage in young rats fed an 18 per cent casein diet and in animals fed a protein-free diet under the conditions of controlled intake of vitamin A.

Six comparable pairs of weanling albino rats of the Yale strain with an average initial weight of $50 \mathrm{gm}$. were chosen for the study. One member of each pair was fed a protein-free diet, while the other member was given an 18 per cent 'vitamin-free' casein diet for a period of 3 weeks. Each animal was kept in a separate cage and was allowed to eat and drink ad libitum. The basal protein-free diet was comparable in composition to that of Rechcigl, Loosli and Williams ${ }^{5}$ with the exception of the vitamin mixture. The vitamins used in this study were supplied in the form of GBI B Complex Dry Mix (purchased from General Biochemicals, Ine.) supplemented with $\alpha$-tocopherol and vitamin D. Vitamin A was given orally to each rat every $48 \mathrm{hr}$. in the form of vitamin A acetate at a level of 30 I.U. Following a 3-week experimental period, the animals were killed and their livers analysed for the vitamin A content by the method of Ames et al. ${ }^{6}$. As a control, vitamin A was also determined in the livers of two additional rats at the beginning of the experiment. The livers of these control animals were found to contain 14.9 and $17.1 \mathrm{kgm}$. vitamin $\mathrm{A}$.

The results of the experiments are shown in Table 1 . The animals which were fed a protein-free diet lost an average of $16 \mathrm{gm}$. body-weight while those fed the casein diet gained $72 \mathrm{gm}$. in a 3 -week experimental period. Despite this large loss of weight, the rats kept on a protein-free ration stored just as much vitamin $\mathrm{A}$ in the liver as did the animals fed a ration supplemented with 18 per cent casein. In fact, the casein-fed rats stored less vitamin $A$ than the animals kept on a protein-free diet. Thus the average liver vitamin A content of the former group was $54.7 \mu \mathrm{gm}$. and that of the latter $96 \cdot 1 \mu \mathrm{gm}$. In view of the considerable difference between the liver weights of the two groups it was of interest to compare the vitamin A content when expressed per
Table 1. GROWTH AND LIVER VITAMIN A STORAGE OF RATS FED 18 PER CENT CASEIN DIET AND PROTEIN-FREE DIET

\begin{tabular}{|c|c|c|c|c|}
\hline \multirow{2}{*}{$\begin{array}{l}\text { Pair No. } \\
\text { and sex }\end{array}$} & \multicolumn{2}{|c|}{ Protein-free } & \multicolumn{2}{|c|}{18 per cent casein } \\
\hline & $\begin{array}{c}\text { Weight gain } \\
\text { (gm./3 weeks) }\end{array}$ & $\begin{array}{c}\text { Vitamin A } \\
(\mu \mathrm{gm} . / \text { liver })\end{array}$ & $\begin{array}{l}\text { Weight gain } \\
\text { (gm./3 weeks) }\end{array}$ & $\begin{array}{c}\text { Vitamin A } \\
(\mu \mathrm{gm} . / \text { liver })\end{array}$ \\
\hline $\begin{array}{ll}1 & 9 \\
2 & 0 \\
3 & 0 \\
4 & 0 \\
4 & 0 \\
5 & 0 \\
6 & 0\end{array}$ & $\begin{array}{l}-13 \\
-13 \\
-16 \\
-15 \\
-19 \\
-20\end{array}$ & $\begin{array}{r}103 \cdot 2 \\
107 \cdot 0 \\
75 \cdot 0 \\
91 \cdot 2 \\
94 \cdot 1 \\
106 \cdot 3\end{array}$ & $\begin{array}{l}70 \\
56 \\
83 \\
71 \\
70 \\
83\end{array}$ & $\begin{array}{l}64 \cdot 4 \\
54 \cdot 1 \\
39 \cdot 6 \\
44 \cdot 0 \\
47 \cdot 3 \\
35 \cdot 5\end{array}$ \\
\hline Average & -16 & $96 \cdot 1$ & 72 & $54 \cdot 7$ \\
\hline
\end{tabular}

unit of weight. The casein-fed rats contained an average of $9 \cdot 3 \mu \mathrm{gm}$. vitamin $\mathrm{A} / \mathrm{gm}$. liver whereas the rats which were kept on a regimen devoid of any protein stored $7 \mathrm{I} \cdot 2 \mu \mathrm{gm} . / \mathrm{gm}$. liver. The lower vitamin $A$ value in the former group can be possibly explained by greater requirement of vitamin A for the purposes of rapid growth.

These results clearly demonstrate that under the given experimental conditions the rats fed a diet lacking in protein were able to store large amounts of preformed vitamin $\mathrm{A}$ in their livers, suggesting that protein is not absolutely essential for this process. This finding is supported by a recent observation of Arnrich and Pederson ${ }^{7}$ that the level of dietary protein has no effect on vitamin A storage in the liver.

M. RECHCIGL, JUN,*

S. Bergert

J. K. LoOSLI

H. H. WIILIIAMS

Department of Animal Husbandry, and

Department of Biochemistry and Nutrition,

Cornell University, Ithaca, New York.

* Present address : Laboratory of Biochemistry, National Cancer Institute, National Institutes of Health, Bethesda, Md.

+ Rockefeller Fellow. Present address: Department of Animal Nutrition, Chief College of Agriculture, Warsaw, Poland.

${ }^{1}$ Basu, N. M., and De, N. K., Sci. and Cult., 6, 672 (1941).

Baumann, C. A. Foster, E. G., and Yoore, P. R., J. Biol. Chem. 142,597 (1942)

${ }^{3}$ Leutskii, K. M., and Leutskaya, Z. K., Doklady Akad. Nauk S.S.S.R., 100, 519 (1955)

- Peretianu, J. M., and Lupu, D. C., Rev. Fiziol., 4, 54 (1957).

${ }^{5}$ Recheigl, jun., M., Loosli, J. K., and Williams, H. H., J. Nut., 63, $177^{\text {(1957). }}$

"Ames, S. R., Risley, H. A., and Harris, P. L., Anal. Chem. 26, 1378 (1954).

${ }^{7}$ Arnrich, L., and Pederson, D. J., Fed. Proc., 15, 212 (1956).

\section{Bioassay of Sheep Anterior Pituitary Glands}

A HIGHLY significant seasonal variation in frequency of twin ovulations in Merino ewes was observed by Radford ${ }^{1}$. In order to determine whether this was correlated with seasonal variation in pituitary gonadotrophin content the surviving ewes from Radford's experiment were later killed16 in mid-summer (January-February 1958) and 11 in mid-winter (June-July 1958). Each ewe was killed 14 days after œstrus.

From examination of the corpora lutea present in the ovaries at slaughter it was determined that seven of the 16 ewes in January-February, and eight of the 11 ewes in June-July had shed two ova at the recorded œstrus. The pituitary glands were removed, trimmed, deep frozen immediately after slaughter, and stored at $-17^{\circ} \mathrm{C}$. In October 1958 , each gland was homogenized with $3 \mathrm{ml}$. distilled water. $1 \mathrm{ml}$. of a buffer (sodium borate, 0.05 ionic strength ; sodium chloride, 0.45 ionic strength ; $p H$ 8.8) was then added to each homogenate. After 